\title{
Antibacterial Activity of Eel (Anguilla spp.) Mucus against Salmonella typhi
}

\author{
Tomy Nurtamin ${ }^{1, *}$, Resty Yulianita Nurman², Indria Hafizah ${ }^{3}$ \\ ${ }^{1}$ Department of Physiology, Faculty of Medicine, Halu Oleo University, Kampus Hijau Bumi Tridharma, Jl. H.E.A. Mokodompit, Kendari, Indonesia \\ ${ }^{2}$ Undergraduate Program, Faculty of Medicine, Halu Oleo University, Kampus Hijau Bumi Tridharma, Jl. H.E.A. Mokodompit, Kendari, Indonesia \\ ${ }^{3}$ Department of Biochemistry, Faculty of Medicine, Halu Oleo University, Kampus Hijau Bumi Tridharma, Jl. H.E.A. Mokodompit, Kendari, Indonesia \\ ${ }^{*}$ Corresponding author. E-mail: tomymedica@gmail.com
}

Received date: Jul 23, 2016; Revised date: Aug 23, 2016; Accepted date: Nov 16, 2016

\section{Abstract}

B ACKGROUND: Typhoid fever has become one global health problem. Typhoid fever is caused by a Gram-negative bacterium, Salmonella typhi. Eel (Anguilla spp.) is a fish which lives in the sea or freshwater. Several previous studies have found that Anguilla spp. mucus has the ability as antibacterial against Gram-positive and negative. Although the antibacterial activity of Anguilla spp. against various pathogens had been reported, very little is known about its activity against Salmonella typhi. The aim of this study was to investigate antibacterial activity of Anguilla spp. mucus against Salmonella typhi bacteria.

METHODS: Present study was an experimental in vitro test. Antibacterial activity assays were carried out by the disc diffusion method. Antibacterial activity was determined by the clear zone formed around the paper disc and minimum inhibitory concentration was determined by observing the lowest concentration which could inhibit the growth of Salmonella typhi.

RESULTS: Result of the present study showed that the Anguilla spp. mucus has inhibitory effects against Salmonella typhi. Minimum inhibitory concentration from the Anguilla spp. mucus was $12.5 \%$.

CONCLUSION: Anguilla spp. mucus has antibacterial activity against the Salmonella typhi bacteria.

KEYWORDS: eel fish mucus, Anguilla spp., antibacterial activity, Salmonella typhi

Indones Biomed J. 2016; 8(3): 179-82

\section{Introduction}

Typhoid fever is a non-communicable disease that has become a global health problem. WHO has reported that approximately 17 million cases of typhoid fever and 600,000 associated deaths occur each year. In Indonesia, one of the typhoid endemic areas, is found an average of 900,000 cases typhoid fever each year with over than 20,000 deaths.(1) Typhoid fever is caused by a Gram-negative bacterium, Salmonella typhi (S. typhi). The transmission of the bacteria usually from ingestion of contaminated food and water. $(1,2)$
Indonesia is one country that has potential aquatic resources where eels living. Eel (Anguilla spp.) is a fish living in the sea or in freshwater.(3) Anguilla spp. is one type of fish that produce mucus. The mucus layer on the surface of fish usually serves as the first line of defense against invasion between fish and its environment. Anguilla spp. mucus contains anti-microbial compounds such as antimicrobial peptide, lysozyme, lectins and protein. Several studies suggest that the mucus of Anguilla spp. has antibacterial activity against pathogenic bacteria, both Gram-negative bacteria such as Edwarsiella tarda, Aeromonas sp, Aeromonas hydrophila, Eschericia coli and Gram-positive bacteria such as Micrococcus leteus, 
Streptococcus difficile.(4-6) Although the antibacterial activity of Anguilla spp. against various pathogens has been reported earlier, very little is known about its activity against S. typhi. Therefore, the present study aimed to investigate antibacterial activity of Anguilla spp. mucus against $S$. typhi bacteria.

\section{Methods}

\section{Sample Collection}

Sample was collected from the Lasolo River, in South Konawe area, South-east Sulawesi, Indonesia by fishermen and was identified by laboratory testing in Faculty of Fisheries, Halu Oleo University. Based on the morphology and zoological taxonomy, the sample was confirmed as Anguilla spp. by zoologist. Sample was kept in container that contains fresh water to increase the mucus production. The mucus was taken from the surface of eel's body by using plastic spatula and was collected into a sterile bottle for about $10 \mathrm{ml}$. Anguilla spp. mucus was made in various concentrations of 100, 50, 25, 12.5 and 6.25\%. Anguilla spp. mucus that had not been diluted was expressed as mucus which has a concentration of $100 \%$, while the other concentrations were prepared by diluting distilled water using the pipetting technique.

\section{Bacterial Strain}

S. typhi was obtained from the collection of microbiology laboratory in Faculty of Medicine, Halu Oleo University, Indonesia. Before the tested bacteria were inoculated, Gram staining was done to make sure that the bacteria tested were not contaminated with other bacteria (Figure 1). The result concluded that the bacteria were S. typhi.

\section{Antibacterial Activity Assays}

Antibacterial assays were carried out by the disc diffusion technique. Clear inhibition zones around the paper discs

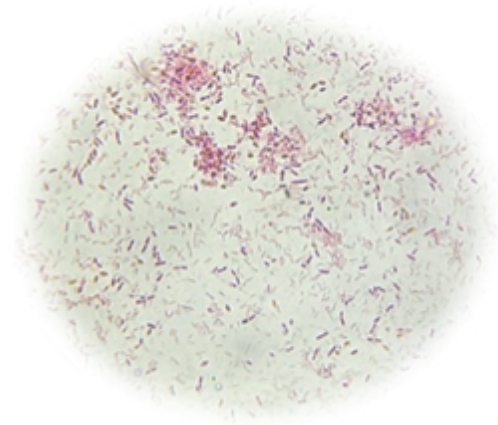

Figure 1. Microscopic image of Gram staining bacteria at 100x magnification. indicated the presence of antibacterial activity of Anguilla spp. mucus. Minimum inhibitory concentration was determined by observing the lowest concentration that can inhibit the growth of S. typhi after incubated for 24 hours at $37^{\circ} \mathrm{C}$.(7) Antibacterial activity assays were performed for three replicates. Ceftriaxone was used against pathogenic bacteria as positive control, while distilled water as negative control.

\section{Results}

The mucus collected from Anguilla spp. showed inhibition in the growth of S. typhi (Table 1 and Figure 2) from antibacterial activity assays. The mucus collected from Anguilla spp. showed inhibition in the growth of $S$. typhi bacteria. Clear inhibition zones around the paper discs indicated the presence of antibacterial activity. Maximum inhibition zones was observed in concentration of $100 \%$ (42.2 $\pm 5.4 \mathrm{~mm}), 50 \%$ (32.0 $\pm 5.9 \mathrm{~mm}), 25 \%(28.3 \pm 1.7 \mathrm{~mm})$, and $12.5 \%(21.0 \pm 4.8 \mathrm{~mm})$. While in concentration of $6.25 \%$ the mucus of Anguilla spp. did not show any inhibition zones, so did the negative control (distilled water). Positive control (Ceftriaxone) showed a zone of inhibition for $48.1 \pm 2.2 \mathrm{~mm}$.

Table 1. Antibacterial activity of the Anguilla spp. mucus (values are the mean of three replicates \pm SD).

\begin{tabular}{cc}
\hline Treatment (concentration in \%) & Inhibition zones (mm) \\
\hline 100 & $42.2 \pm 5.4$ \\
50 & $32.0 \pm 5.9$ \\
25 & $28.3 \pm 1.7$ \\
12.5 & $21.0 \pm 4.8$ \\
6.25 & 0 \\
Ceftriaxone (positive control) & $48.1 \pm 2.2$ \\
Distilled water (negative control) & 0 \\
\hline
\end{tabular}

\section{Discussion}

The emergence of multi-drugs bacterial resistance in many endemic areas of S. typhi should be reduced.(1) The reports on the antibacterial activity of natural products against the pathogens are promising to be developed. Present study 


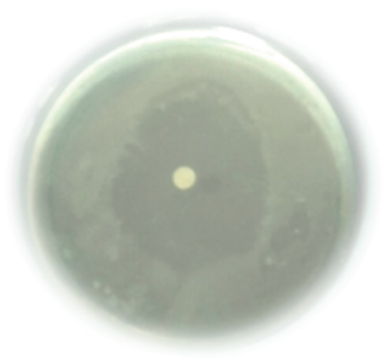

Concentration of $100 \%$

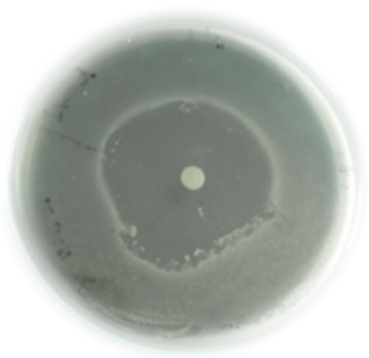

Concentration of $50 \%$

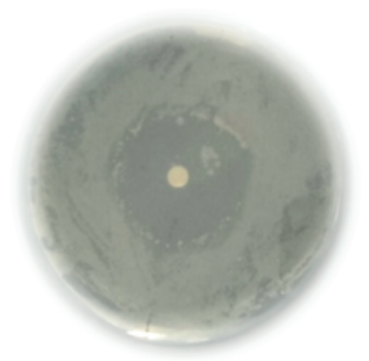

Concentration of $25 \%$

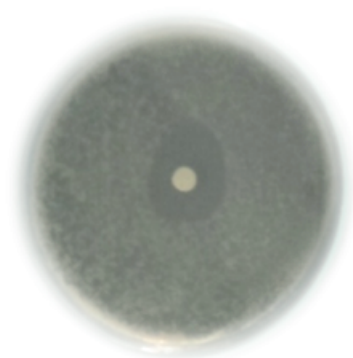

Concentration of $12.5 \%$

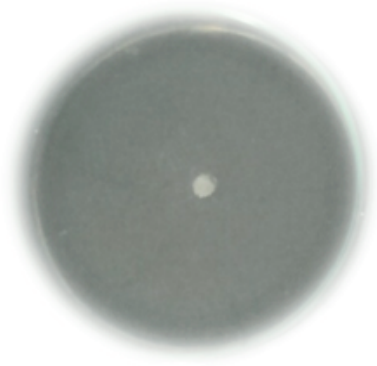

Concentration of $6.25 \%$

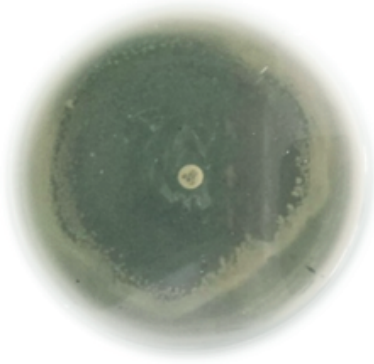

Positive Control

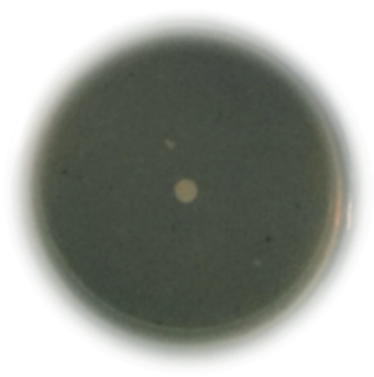

Negative Control

Figure 2. The comparative antibacterial activity of Anguilla spp. mucus with negative and positive control.

was carried out to investigate the antibacterial activity of Anguilla spp. mucus against S. typhi. In our study, we found that Anguilla spp. mucus has potential activity against S. typhi. Anguilla spp. mucus has strong ability to inhibit the growth of S. typhi bacteria in the concentration of $100 \%$ and minimum inhibitory concentration in the concentration of $12.5 \%$.

The epidermal layer of fish contains specialized glandular cells that produce mucus. The mucus layer of fish contains a variety of materials such as lectin, lisozyme and protein which has antibacterial activity that provide a first line of defense system against invading bacteria. $(8,9)$ It has been reported that protein extracted from fish's epidermal mucus acts as antibacterial by a pore formation in cell membranes bacteria.(10)

Mucus of Anguilla Japonica has been known to contains two lactose-specific lectins, which are Anguilla japonica lectin (AJL)-1 and AJL-2, that act as antibacterial by agglutinate and suppression growth of both Gram-positive and Gram-negative bacteria. $(5,9)$ Lectin has important role in innate immune defense by activation of the classical complement pathway.(11) It has been reported that mucus of Anguilla japonica contain AJN-10, a heat-tolerant and hydrophilic peptide, showed strong antibacterial activity against Aeromonas hydrophila.(4) Thus, skin mucus of eel needs to be characterized further, and can be explored as a potent antibacterial against $S$. typhi. Further study is needed to explore the bioactive molecule and its mechanism responsible for antibacterial against $S$. typhi bacteria.

\section{Conclusion}

Anguilla spp. mucus has an ability to inhibit the growth of S. typhi, because of its antibacterial activity against the S. typhi bacteria. Thus, this study suggests that Anguilla spp. mucus is a promising biopharmaceutical compound that can be effectively used against the $S$. typhi bacteria.

\section{References}

1. World Health Organization. Background document: the diagnosis, treatment and prevention of typhoid fever. 2003. Available from: http://www.who.int/rpc/TFGuideWHO.pdf.

2. Stearns SC, Koella JC. Evolution in Health and Disease. 2nd ed. New York: Oxford University Press; 2008.

3. Arai T, Limbong D, Otake T, Tsukamoto K. Metamorphosis and inshore migration of tropical eels Anguilla spp. in the Indo-Pacific. Mar Ecol Prog Ser. 1999; 182: 283-93.

4. Liang Y, Guan R, Huang W, Xu T. Isolation and identification of a novel inducible antibacterial peptide from the skin mucus of Japanese eel, Anguilla japonica. Protein J. 2011; 30: 413-21.

5. Tasumi S, Yang WJ, Usami T, Tsutsui S, Ohira T, Kawazoe I, et al. Characteristics and primary structure of a galectin in the skin mucus 
of the Japanese eel, Anguilla japonica. Dev Comp Immunol. 2004; 28: 325-35.

6. Rao V, Marimuthu K, Kupusamy T, Rathinam X, Arasu MV, AlDhabi NA, et al. Defense properties in the epidermal mucus of different freshwater fish species. AACL Bioflux. 2015; 8: 184-94.

7. Andrews JM. Determination of minimum inhibitory concentrations. J Antimicrob Chemother. 2001; 48 (Suppl 1): 5-16.

8. Subramanian S, Ross NW, MacKinnon SL. Comparison of antimicrobial activity in the epidermal mucus extracts of fish. Comp Biochem Physiol B Biochem Mol Biol. 2008; 150: 85-92.
9. Tasumi S, Ohira T, Kawazoe I, Suetake H, Suzuki Y, Aida K. Primary structure and characteristics of a lectin from skin mucus of the Japanese eel, Anguilla japonica. J Biol Chem. 2002; 30 :27305-11.

10. Ebran N, Julien S, Orange N, Saglio P, Lemaitre C, Molle G. Poreforming properties and antibacterial activity of proteins extracted from the epidermal mucus of fish. Comp Biochem Physiol. 1999; 122: 181-9.

11. Avni O, Pur Z, Yefenof E, Baniyash M. Complement receptor 3 of macrophages is associated with galectin-1-like protein. $J$ Immunol.1998; 160: 6151-8. 